\title{
Application Of Certainty Factor Methods To Diagnose Gastrointestinal Worm Infections In Sumatran Tigers
}

\author{
Firahmi Rizky ${ }^{1}$, Nizwardi Jalinus², Sukardi ${ }^{3}$, AsyahriHadi Nasyuha ${ }^{4}$, Yohanni Syahra ${ }^{5}$ \\ ${ }^{1}$ Information Of System, STMIK Triguna Dharma, Indonesia \\ ${ }^{2}$ Faculty of Engineering, Universitas Negeri Padang, Indonesia \\ ${ }^{3}$ Faculty of Engineering, Universitas Negeri Padang, Indonesia \\ ${ }^{4}$ Information Of System, STMIK Royal Kisaran, Indonesia \\ ${ }^{5}$ Information Of System, STMIK Triguna Dharma, Indonesia
}

Article History: Received: 11 January 2021; Accepted: 27 February 2021; Published online: 5 April 2021

\begin{abstract}
Gastrointestinal worm infection affects the Sumatran tiger. Due to the lack of tools to diagnose the disease, the Sumatran tigers are very often located in Medan Zoo, North Sumatra, and their handling is very rare.Based on the above problems, we need an application in the form of an expert system by applying the Certainty Factor method which is expected to help in diagnosing Gastrointestinal worm infection in Sumatran tigers. With the existing symptoms, the CF value can be determined to get a diagnosis of Gastrointestinal worm infection. So that it can make it easier for a doctor to treat and diagnose gastrointestinal worm infections in Sumatran tigers. The conclusion obtained from the system, is able to diagnose quickly, precisely and accurately the symptoms of gastrointestinal worm infections and is expected to help the community in diagnosing gastrointestinal worms experienced by Sumatran tigers so that treatment can be carried out immediately. This is an open access article under the CC BY-SA license
\end{abstract}

Keyword: Gastrointestinal Worm Infections; Expert System;Certainty Factor

\section{Introduction}

The Sumatran tiger is a land mammal that is included in the world big cat group and protected wildlife in Indonesia because it is an endangered animal such as the Javan tiger and the Bali tiger. In the Medan Wildlife Park area, there are 8 cages containing tigers. Each cage contains 2 tigers, and only 1 cage contains one tiger. The sleeping cages in each area are the same size, have a cement floor, contain a wooden table for the tiger to sleep on, and a small drinking tub. The enclosure of open area for resting and playing is designed to resemble its natural habitat, with several play areas the same size. There are trees, grass, and ponds [1].The Sumatran tiger Panthera tigris sumatrae is endemic to the island of Sumatra, which has the smallest average body size among the extant tiger subspecies. Endemic animals are natural animal species that reside in a certain area or area and make the area unique because they are not found in other areas.Male Sumatran tigers have a body weight of $\pm 120 \mathrm{~kg}$ and an average length of $240 \mathrm{~cm}$ from head to tail. While the female has a weight of $\pm 90 \mathrm{~kg}$ and the average length from head to tail is $220 \mathrm{~cm}$. Tigers are solitary animals, rarely found in pairs, except for tigers and their cubs. Tigers can communicate through smells and sounds. Tigers have a strong sense of smell and often leave a mark of urine with a characteristic odor. These signs function as road markers, territorial markers or as a means of communicating more specific information such as individual identities, the period of time that individual tigers pass over a certain area, and markers of estrus in tigers [2]. Sumatran tigers are categorized into the Critically Endangered category which means very critical and endangered by the conservation organization International Union for Conservation of Nature (IUCN), IUCN is an agency that regulates wildlife trade. An expert system is a computer-based intelligent system that is used in problem solving and can only be done by an expert / expert in a particular field. With this intelligent system the general public can use and perform calculations like an expert [3]. The knowledge that can be obtained in an expert system is generally taken from a human who is an expert in the problem. The important role of an expert can be replaced by a computer program and then its work is to provide the right and definite solution as is usually done by experts. Expert systems are usually used for consultation, analysis, diagnosis, and help make decisions that can be applied using one method, namely Certainty factor (CF). Certainty Factor (Factor of Uncertainty) states belief in an event (fact or hypothesis) based on evidence or expert judgment. Certainty Factor uses a value to assume the degree of an expert's confidence in a data. Certainty Factor introduces the concept of belief and uncertainty [4]

\section{Research methods}

2.1 Expert System

There are several according to experts regarding expert systems.An expert system is a computer program that has knowledge or knowledge of one or more human expertise in a particular field that shows or shows policies like an expert [5].The ability of an expert to solve system problems is designed to imitate his expertise when answering questions and solving problems in both the field of an important role [6].The term expert system is a branch of artificial intelligence. Artificial intelligence (AI) is very old because this system was developed in 1960.This system can work to adopt human science to computers that connects the knowledge base that can replace an expert to solve anproblem. 


\subsubsection{Benefits of Expert System}

In this technological era, expert systems have become a very popular science, therefore this ability can be useful for ordinary people. Therefore, in broad outline there are several benefits that can be taken by the existence of an expert system, as follows [8].

1. Have the ability to work with various information that does not contain certainty.

2. Can increase the ability about computers.

3. Have the ability to access knowledge.

4. Can operate for very hazardous environments.

5. Can enable ordinary people to do the work of experts.

6. Can do the process repeatedly - automatically again.

7. Can improve quality.

8. Increase output and productivity.

9. Increase the capability to complete a period.

\subsubsection{Advantages of Using Expert Systems}

1. Allows ordinary people to do the work of experts.

2. Can do the process repeatedly and automatically.

3. Save the knowledge and expertise of experts.

4. Increase output and productivity.

5. Can increase the quality or quality.

6. Improve quality power, and provide consistent advice and reduce errors.

7. Gives convenience to an expert.

\subsubsection{Weaknesses of Expert System}

The weaknesses of the expert system are as follows [13]:

1. Expert system development is very difficult, more difficult than making a software.

2. The value of expert systems is very expensive, the effort to develop, try and deliver to the end user requires high costs.

3. The expert system is not $100 \%$ reliable, even though at the time of manufacture it has been consulted with experts that either the expert system is still imperfect or not always correct.

\subsection{Certainty Factor}

The Certainty Factor method is a method that proves whether a fact is certain or uncertain in the form of a metric that is usually used in expert systems. This method is also very suitable for expert systems to diagnose anything that is uncertain. Certainty Factor (CF) is a method proposed by Shortliffe and Buchanan in 1975 to accommodate an expert's inexact reasoning. An expert (eg a doctor) often analyzes information with the phrase "maybe", "most likely", "almost certain". So that the existence of the Certainty Factor method can describe the level of confidence of an expert on the problem at hand [14]. To solve things like this, certainty factors (CF) can be used to describe the level of expert confidence in those faced. There are several certainty factor formulas that are commonly used by experts to calculate the value of a single premise, which are as follows: The formula for getting the confidence level $(\mathrm{CF})$ from a rule, namely:

$\mathrm{CF}($ Rule $)=\mathrm{MB}(\mathrm{H}, \mathrm{E})-\mathrm{MD}(\mathrm{H}, \mathrm{E})$

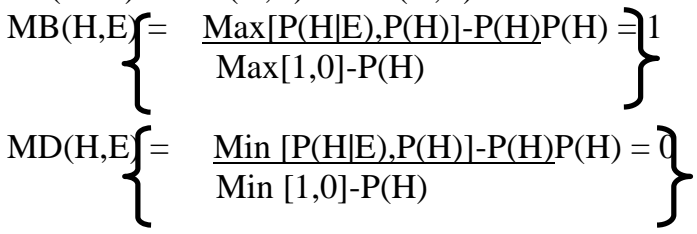

Information:

(CF) Rule: The factor of certainty

MB (H, E): Measure Of Belief (Size of Trust) against hypothesis H,

If evidence is provided (between 0 and 1 ).

MD (H, E): Measure Of Disbelief evidence $H$,

If given evidence $\mathrm{E}$ (between 0 and 1 ).

$\mathrm{P}(\mathrm{H})$ : Probability of the truth of the hypothesis $\mathrm{H}$.

$\mathrm{P}(\mathrm{H} \mid \mathrm{E})$ : The probability that $\mathrm{H}$ is true because of fact $\mathrm{E}$

Table 1. Term CF 


\begin{tabular}{clc}
\hline Uncertain Term & \multicolumn{2}{c}{ CF } \\
\hline Definitely not & - & 1.0 \\
\hline $\begin{array}{c}\text { Almost certainly } \\
\text { not }\end{array}$ & - & 0.8 \\
\hline Probably not & - & 0.6 \\
\hline Maybe not & - & 0.4 \\
\hline Uknown & 0.2 to 0.2 \\
\hline Maybe & \multicolumn{2}{c}{0.4} \\
\hline Probably & 0.6 \\
\hline Almost certainly & 0.8 \\
\hline
\end{tabular}

\subsection{System Design Methods}

In system design, a method used in software design is required. The method that researchers use in this preparation is the waterfall algorithm.

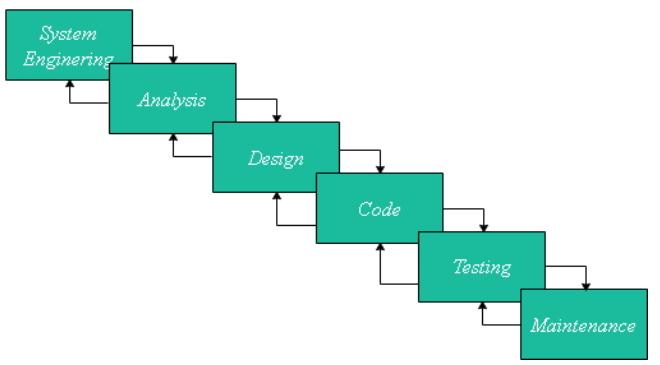

Figure 1. WaterfallModel

In this research, a system design method can be done, namely the waterfall algorithm. There are several steps that can be taken in this research, namely as follows:

1. Analysis of Problems and Needs

Analysis of problems and needs is the stages from the beginning in system design. At this stage, it will be ascertained where the real problem point or problem is and what elements are needed to solve the problem of diagnosing Gastrointestinal worm infection.

2. System Design

In this phase there are several indicators or elements, namely; (1) system modeling with the Unified Modeling Language, (2) modeling using a system flowchart, (3) input design, and (4) output design from an expert system to diagnose gastrointestinal worm infections.

3. System Builders

This stage describes the steps for coding the system design that is designed both from the input, process and output systems using the Visual Basic programming language.

4. System Trial

This step is the most important step for the development of an expert system. This can be because in this step trial and error is carried out on all aspects of the application both coding. System design and modeling of expert systems to diagnose gastrointestinal worm infections.

5. Implementation or Maintenance.

This final step is a step where the use of the application by stakeholders who will use this system. In this study, the end user is a doctor who has the authority to examine gastrointestinal worms.

\subsection{Flowchart}

A flowchart or flow chart is a diagram with graphic symbols representing the flow of an algorithm or process showing the steps symbolized in the form of a box, along with their sequence by connecting each of these steps using arrows [16]. The use of flowcharts functions for a stage and solves a problem in a simple and detailed manner. Flowchart is a work symbol that shows a flowchart that is in process and is connected to one another. Therefore, each flowchart symbol can symbolize a job and provide instructions. Algorithm is an idea or someone's idea to solve a problem that must be put in writing. But algorithms have a very important role, especially for building a program. This can be because each code must have the right algorithm so that it can work as well and get the desired results by using standard image symbols / symbols on computers, namely the image symbols on the flowchart. When using a flowchart symbol (flow chart), a programmer distributes his ideas 
or ideas listed so that every other programmer can understand them well., A flowchart is a chart that can be used to explain a system flow using certain symbols [17]. As follows are the symbols listed in the flowchart, namely:

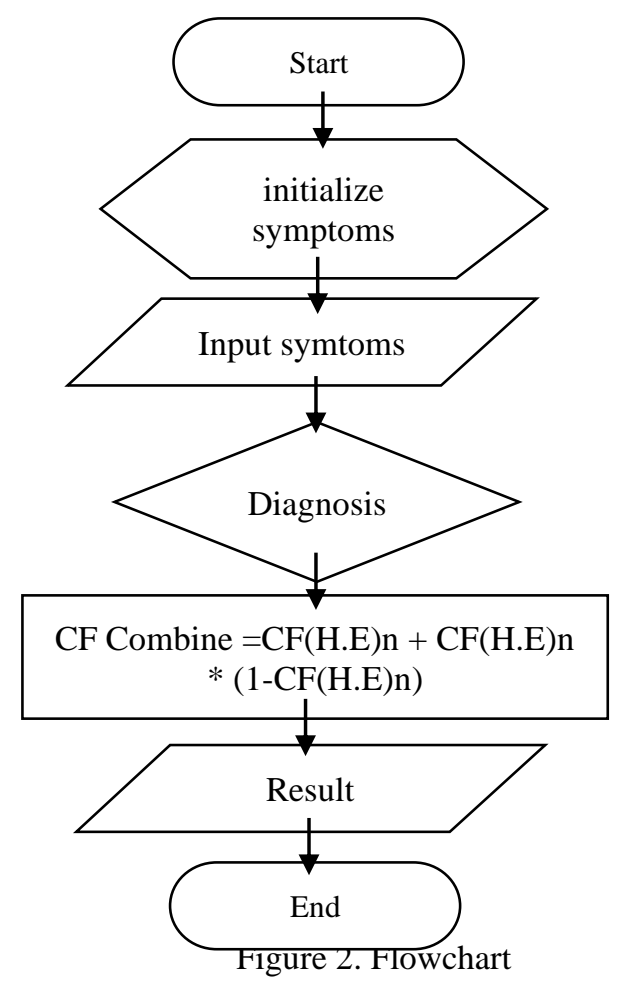

\section{Analysis}

\subsection{Determining Symptoms and Disease Data}

An expert system is an information system that contains an expert's knowledge so that it can be used to share knowledge. Expert knowledge possessed by this expert system is used as a basis for answering questions. The success of an expert system is found from the knowledge of the experts or experts who are adopted, and how to manage the knowledge obtained from the interview results into a disease table to make it easier to diagnose Gastrointestinal worm infection in Sumatran tigers. In the table below, you can see the symptoms of Gastroistestinal worm infection in Sumatran tigers.

Table 2. Disease Data

\begin{tabular}{ccc}
\hline No & Disease & Code Disease \\
\hline 1 & InfeksiCacingToxocara & P001 \\
\hline 2 & InfeksiCacingToxascaris & P002 \\
\hline
\end{tabular}

Tabel 3. Symptom Data

\begin{tabular}{clc}
\hline No & \multicolumn{1}{c}{ Symptom } & Code Symptom \\
\hline 1 & Vomiting Diarrhea & G001 \\
\hline 2 & Anemia & G002 \\
\hline 3 & Hair Loss & G003 \\
\hline 4 & Experiencing Weaknesses & G004 \\
\hline 5 & Bleeding in the digestive tract & G006 \\
\hline 6 & Dry Cough & G007 \\
\hline 7 & Depression & G008 \\
\hline 8 & Liver Swelling & G009 \\
\hline 9 & Lack of Appetite & G010 \\
\hline 10 & Inflammation of the Eyes & G011
\end{tabular}

\subsection{Tree Disease Rules Based on Symptoms}

From the decision table above, it can be concluded that the rules for diagnosing Gatrointestinal worm infection in Sumatran tigers are as follows: 
Rule 1: IF type of symptoms G01 AND G02 AND G03 AND G04 AND G05 AND G06 THEN have Toxocara worm infection.

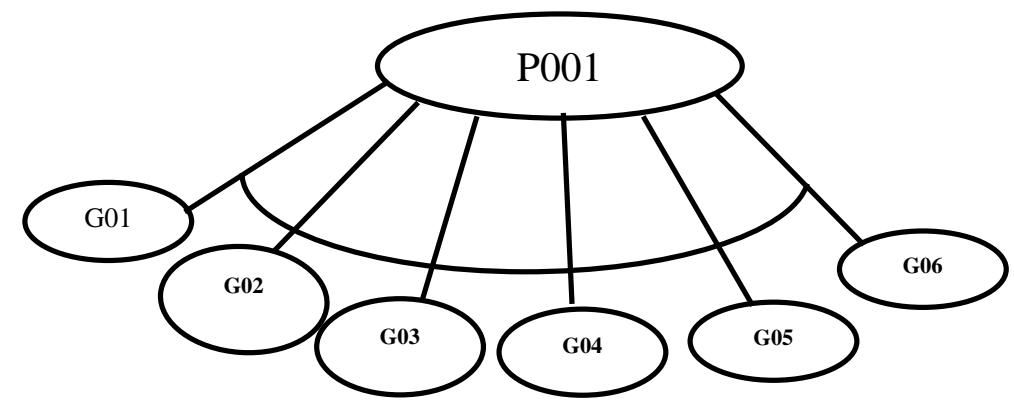

Figure 3. Toxocara Worm Infection Decision Tree

Rule 2: IFSymptoms G06 AND G07 AND G08 AND G09 AND G10 AND G11 THEN have Toxascaris worm infection.

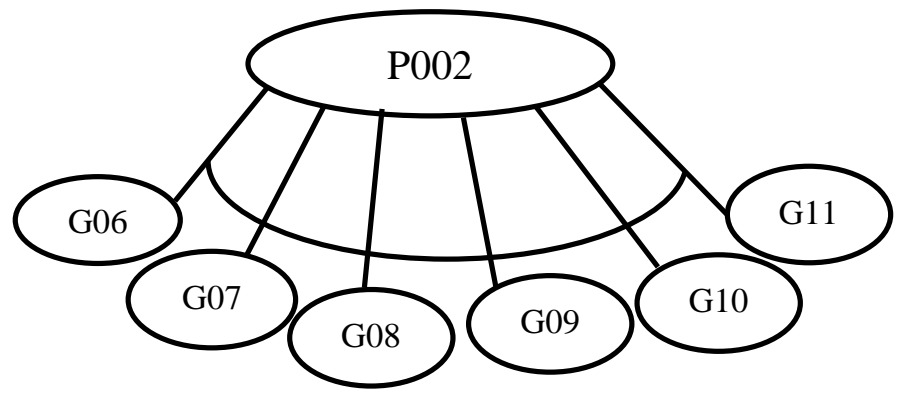

Figure 4. Toxascaris worm infection decision tree

\subsection{Determining the Value of CFpar and Value of CFuser}

Determine the CFpakar value for each of the following characteristics:

Table 4. Determining Expert CF Value

\begin{tabular}{lllc}
\hline & $\mathrm{N}$ & Code Symptom & $\begin{array}{c}\text { Value } \\
\text { Symptom }\end{array}$ \\
\hline & & Vomiting Diarrhea & 0.8 \\
\hline 2 & Anemia & 0.9 \\
\hline 3 & Hair Loss & 0.7 \\
\hline 4 & Experiencing Weaknesses & 0.6 \\
\hline 5 & Bleeding in the digestive tract & 0.9 \\
\hline & 6 & Dry Cough & 0.6 \\
\hline & 7 & Depression & 0.8 \\
\hline & 8 & Liver Swelling & 0.8 \\
\hline & 9 & Lack of Appetite & 0.9 \\
\hline & 1 & Inflammation of the Eyes & 0.7 \\
\hline & 1 & Skinny & 0.9 \\
\hline
\end{tabular}

Determine the CFuser value for each of the following features:

Table 5. User Values

\begin{tabular}{lclll}
\hline & $\mathrm{N}$ & $\begin{array}{c}\text { Characteris } \\
\text { tic Code }\end{array}$ & Certainty Term & Value CFuser \\
\hline 1 & G01 & Sure enough & 0.4 \\
\hline 2 & G02 & Possible & 0.6 \\
\hline
\end{tabular}




\begin{tabular}{|c|c|c|c|}
\hline 3 & G03 & Possible & 0.6 \\
\hline 4 & G04 & Sure & 0.8 \\
\hline 5 & G05 & Possible & 0.6 \\
\hline 6 & G06 & Sure enough & 0.4 \\
\hline 7 & G07 & Possible & 0.6 \\
\hline 8 & G08 & Possible & 0.6 \\
\hline 9 & G09 & Sure & 0.8 \\
\hline $0^{1}$ & G10 & Possible & 0.6 \\
\hline $\begin{array}{ll} & 1 \\
1 & \end{array}$ & G11 & Very Confident & 1 \\
\hline
\end{tabular}

1. Calculation Process for Certainty Factor

The next step, by transferring the CFpakar value with the CFuser value. Here are the calculations: $\mathrm{CF}[\mathrm{H}, \mathrm{E}]=\mathrm{CF}[\mathrm{H}] * \mathrm{CF}[\mathrm{E}]$

$\begin{array}{ll}\text { CF } 1.1 & : 0,8 * 0,4=0,32 \\ \text { CF } 1.2 & : 0,9 * 0,6=0,54 \\ \text { CF } 1.3 & : 0,7 * 0,6=0,42 \\ \text { CF } 1.4 & : 0,6 * 0,8=0,48 \\ \text { CF } 1.5 & : 0,9 * 0,6=0,54 \\ \text { CF } 1.6 & : 0,6 * 0,4=0,24 \\ \text { CF } 1.7 & : 0,8 * 0,6=0,48 \\ \text { CF } 1.8 & : 0,8 * 0,6=0,48 \\ \text { CF } 1.9 & : 0,9 * 0,8=0,72 \\ \text { CF } 1.10 & : 0,7 * 0,6=0,42 \\ \text { CF } 1.11 & : 0,9 * 1=0,9\end{array}$

Combine values $\mathrm{CF}[\mathrm{H}, \mathrm{E}]=\mathrm{CF}[\mathrm{H}, \mathrm{E}]+\mathrm{CF}[\mathrm{H}, \mathrm{E}] *(1-\mathrm{CF}[\mathrm{H}, \mathrm{E}])$

Calculation of the Toxocara Worm Infection Manual

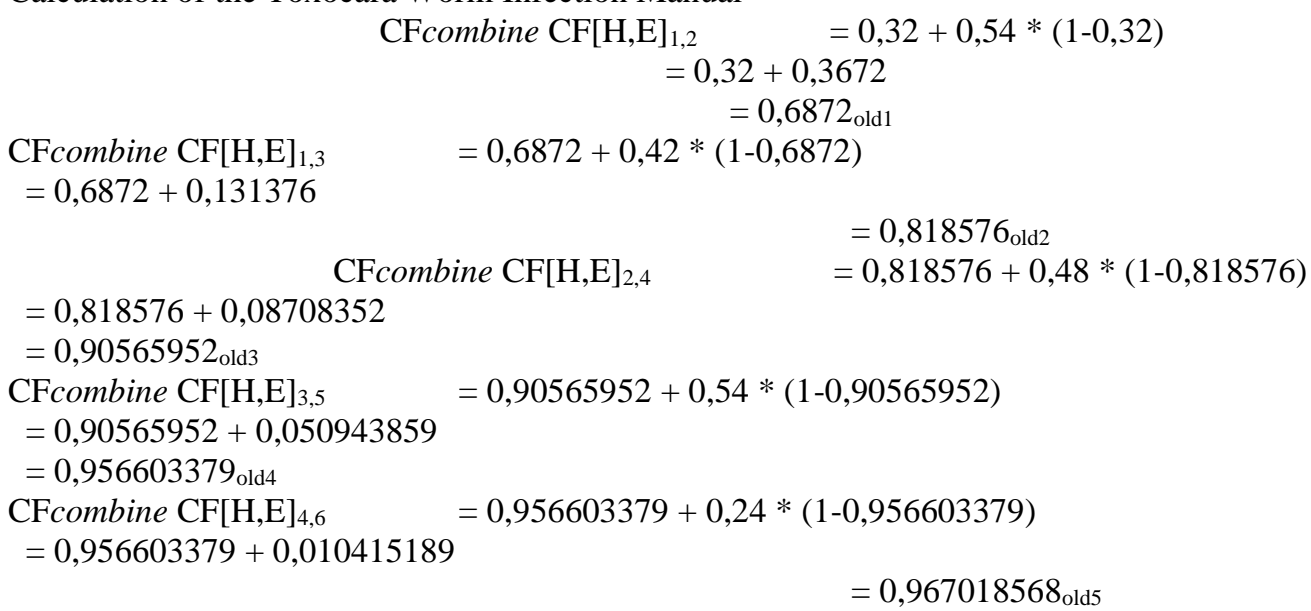

Then the CF of the symptoms entered by the user for Toxocara worm infection is likely to be 0.967018568 . Percentage yield $=0.967 * 100 \%=96.7 \%$. Calculation of Toxascaris Worm Infection Manual.

CFcombine CF $[\mathrm{H}, \mathrm{E}] 6.7=0.24+0.48 *(1-0.24)=0.24+0.3648=0.6048 \mathrm{old} 6$

CFcombine CF [H, E] $6.8=0.6048+0.48 *(1-0.6048)=0.6048+0.189696=0.794496$ old 7

CFcombine CF $[\mathrm{H}, \mathrm{E}] 7.9=0.794496+0.72 *(1-0.794496)=0.794496+0.14796288=0.94245888$ old 8

CFcombine CF [H, E] $8.10=0.94245888+0.42 *(1-0.94245888)=0.94245888+0.041429606=$ 0.983888486 old 9

CFcombine CF $[\mathrm{H}, \mathrm{E}] 9.11=0.983888486+0.9 *(1-0.983888486)=0.983888486+0.014503626=$ 0.998392112 old10

Then the CF of the symptoms entered by the user for Toxascaris Worm Infection is likely to be 0.998392112. Percentage yield $=0.998 * 100 \%=99.8 \%$ 


\section{Conclusion}

From the results of diagnosing gastrointestinal worm infections in Sumatran tigers using the Certainty Factor method, it can be concluded that:

1. In diagnosing Gastrointestinal worm infection, it must be based on the symptoms experienced by the Sumatran tiger.

2. The application of the Certainty Factor method expert system is implemented in a case study, namely Medan Zoo North Sumatra with expert veterinarians as an information tool for diagnosing diseases in Sumatran tigers, which doctors use is to select symptoms that occur in Sumatran tigers and process by the system so as to get reports of Gastroistestinal worm infections experienced by Sumatran tigers.

3. Based on the research results, the expert system design can be used in the process of diagnosing gastrointestinal worm infections in Sumatran tigers.

4. Expert system application to diagnose Gastointestinal worm infection with the Certainty Factor method is designed into the form of UML modeling which consists of use case diagrams, activity diagrams, class diagrams which are then coded by designing them into Desktop Programming.

5. Based on the research results, the expert system design can be used in the process of diagnosing gastrointestinal worm infections in Sumatran tigers.

\section{Reference}

1. S. Panthera, T. Sumatrae, D. A. N. Harimau, P. Tigris, D. I. Taman, and M. Medan, “1 , 2 , 3 1,” vol. 3, no. 3, pp. 126-132, 2019.

2. A. Ganesa, "Perilaku Harian Harimau Sumatera (Panthera tigris sumatrae) dalam konservasi ex-situ Kebun Binatang Surabaya Ari,” J. Sains Dan Seni Its, vol. 1, no. 1, pp. 48-53, 2012.

3. B. Y. T. Astono, M. S. Febrian, W. P. Laksana, and R. I. Laveri, "Sistem Pakar Diagnosa Penyakit Kucing Feline Virus Menggunakan Metode Certainty Factor Berbasis Web," vol. VI, no. September, 2019.

4. F. Rahmi Ras, H. Nelly Astuti, and B. Efori, "Perancangan Sistem Pakar Diagnosa Penyakit Asidosis Tubulus Renalis Menggunakan Metode Certainty Factor Dengan Penelusuran Forward Chaining," Media Inform. Budidarma, vol. 1, no. 1, pp. 13-16, 2017.

5. N. A. Hasibuan, H. Sunandar, S. Alas, and S. Suginam, "Sistem Pakar Mendiagnosa Penyakit Kaki Gajah Menggunakan Metode Certainty Factor," Jurasik (Jurnal Ris. Sist. Inf. dan Tek. Inform., vol. 2, no. 1, p. 29, 2017, doi: 10.30645/jurasik.v2i1.16.

6. M. A. Irfandi, A. Romadhony, and S. Saadah, "Implementasi Sistem Pakar Diagnosa Penyakit Gigi Dan Mulut Menggunakan Metode Hybrid Case-Based Dan Rule-Based Reasoning,” no. April 2017, 2015, doi: 10.21108/indosc.2015.19.

7. D. Alfrido and T. K. Gautama, "Sistem Pakar Deteksi Kerusakan Sepeda Motor dengan Metode Forward Chaining," J. Tek. Inform. dan Sist. Inf., vol. 3, no. 3, pp. 618-636, 2017, doi: 10.28932/jutisi.v3i3.705.

8. T. A. Rahman, Fakhrul; Mandala, Eka Praja Wiyata; Putra, "Perancangan Aplikasi Sistem Pakar Dengan Menggunakan Metode Certainty Factor Untuk Menentukan Jenis Gangguan Disleksia Berbasis Web," J. INKOFAR, vol. 1, no. 1, pp. 12-17, 2017.

9. L. Septiana, "Perancangan Sistem Pakar Diagnosa Penyakit Ispa Dengan Metode Certainty Factor Berbasis Android," None, vol. 13, no. 2, pp. 1-7, 2016.

10. H. Sujadi and E. Suhaeni, "Sistem Pakar Penyakit Dengan Gejala Demam Menggunakan Perangkat Mobile Berbasis Android," Semin. Nas. Teknol. Inf. dan Komun., vol. 2016, no. Sentika, pp. 20899815, 2016.

11. S. Nurajizah and M. Saputra, "Sistem Pakar Berbasis Android Untuk Diagnosa Penyakit Kulit Kucing Dengan Metode Forward Chaining," None, vol. 14, no. 1, pp. 7-14, 2018, doi: https://doi.org/10.33480/pilar.v14i1.81.

12. A. A. Sofyan, Z. Hakim, M. I. Dzulhaq, and A. Mursofi, "Perancangan Aplikasi Sistem Pakar Deteksi Dini Kerusakan Mobil Toyota Avanza," J. Sisfotek Glob., vol. 5, no. 1, pp. 4-9, 2015.

13. G. A. D. Sugiharni and D. G. H. Divayana, "Pemanfaatan Metode Forward Chaining Dalam Pengembangan Sistem Pakar Pendiagnosa Kerusakan Televisi Berwarna," J. Nas. Pendidik. Tek. Inform., vol. 6, no. 1, p. 20, 2017, doi: 10.23887/janapati.v6i1.9926.

14. M. Muqorobin, P. B. Utomo, M. Nafi'Uddin, and K. Kusrini, "Implementasi Metode Certainty Factor pada Sistem Pakar Diagnosa Penyakit Ayam Berbasis Android," Creat. Inf. Technol. J., vol. 5, no. 3, p. 185, 2019, doi: 10.24076/citec.2018v5i3.198.

15. K. E. Setyaputri and A. Fadlil, "Analisis Metode Certainty Factor pada Sistem Pakar Diagnosa Penyakit THT,” J. Tek. Elektro, vol. 10, no. 1, pp. 30-35, 2018. 
16. W. Supartini and H. Hindarto, "Sistem Pakar Berbasis Web Dengan Metode Forward Chaining Dalam Mendiagnosa Dini Penyakit Tuberkulosis Di Jawa Timur," Kinetik, vol. 1, no. 3, p. 147, 2016, doi: 10.22219/kinetik.v1i3.123.

17. P. N. Afifah, "Rancang Bangun Sistem Pakar Bimbingan Konseling Kesulitan Belajar Siswa dengan Menggunakan Metode Forward Chaining Studi Kasus di SMPN 1 Mejayan,” pp. 217-223, 2019.

18. H. T. SIHOTANG, "Sistem Pakar Untuk Mendiagnosa Penyakit Pada Tanaman Jagung Dengan Metode Bayes," vol. 3, no. 1, 2019, doi: 10.31227/osf.io/dguhb.

19. H. T. Sihotang, "Sistem Pakar Mendiagnosa Penyakit Kolesterol Pada Remaja Dengan Metode Certainty Factor (Cf) Berbasis Web," J. Mantik Penusa, vol. 15, no. 1, pp. 16-23, 2014.

20. N. Firmansyah, "Sistem Pakar Indentifikasi Pengecekan Kualitas Kupi Berbasis Web Dengan Menggunakan Metode Certainty Factor," J. Rekursif, vol. 5, no. 3, pp. 298-306, 2017.

21. Husein, Ismail H Mawengkang, S Suwilo "Modeling the Transmission of Infectious Disease in a Dynamic Network" Journal of Physics: Conference Series 1255 (1), 012052, 2019.

22. Husein, Ismail, Herman Mawengkang, SaibSuwilo, and Mardiningsih. "Modelling Infectious Disease in Dynamic Networks Considering Vaccine." Systematic Reviews in Pharmacy 11.2, pp. 261-266, 2020.

23. Husein, Ismail, DwiNoerjoedianto, Muhammad Sakti, AbeerHamoodi Jabbar. "Modeling of Epidemic Transmission and Predicting the Spread of Infectious Disease." Systematic Reviews in Pharmacy 11.6 (2020), 188-195. Print. doi:10.31838/srp.2020.6.30

24. Husein, Ismail, YD Prasetyo, S Suwilo "Upper generalized exponents of two-colored primitive extremal ministrongdigraphs"AIP Conference Proceedings 1635 (1), 430-439, 2014

25. Husein Ismail, RahmadSyah, "Model of Increasing Experiences Mathematics Learning with Group Method Project", International Journal of Advanced Science and Technology, pp. 1133-1138, 2020.

26. N. Nazarudin, A. Saputra, and H. Khumaini, "Sistem Pakar Diagnosa Kerusakan Mesin Sepeda Motor Yamaha Di Compion Motor Dumai," I $N F O R M a T I K a$, vol. 9, no. 1, p. 70, 2017, doi: 10.36723/juri.v9i1.86. 